Bataeva E.V., Dr Habil. in Philosophy, Professor, Department of Sociology and Humanities, Kharkov University of Humanities "People's Ukrainian Academy", 27, Lermontovska Str., Kharkiv, 61000, Ukraine, email: bataevaekaterina72@yahoo.com, ORCID iD: https://orcid.org/0000-0002-46284817, Scopus Author ID: 57204186366,

Artemenko A.B., PhD. in Sociology, Head of the Department of Social Rehabilitation Technologies, Zhytomyr Institute for Economics and Humanities, 18, Vilsky Shlyakh Str., Zhytomyr, 10020, Ukraine, email: a.b.renkas@ukr.net,ORCID iD: https://orcid.org/0000-0002-9924-7411

\title{
INFLUENCE OF MILITARY IDENTITY ON SOCIAL ADAPTATION OF UKRAINIAN VETERANS
}

The article examines the influence of different forms of the military identity of veterans on the degree of their social adaptation. We define "military identity" as a result of the social identity of a service(wo)man with the military due to the internalization of values and norms adopted in the military sphere. A "veteran" is a service(wo)man who served in the army, participated in combat operations, and was demobilized in connection with the end of the term of service or for health reasons, regardless of the types of military forces and military service. We have used a sociological method of measuring the stable, situational, and unformed types of veterans' military identity based on the following criteria: social identification, the strength of connection with the army, biographical importance of military service, perception of the army as a family, recognition of the individual in the army, existential assessment of military service, the importance of military practices after demobilization, social contacts with former service(wo)men, the positive assessment of the military culture of obedienceldiscipline. We have studied the influence of the following factors - duration of staying in the combat zone, conscription age, motivation to join the army, marital status, and traumatic combat experience - on the formation of military identity. According to the quota sample, the results of the study "Military identity and social adaptation of Ukrainian veterans" are presented; 400 veterans $(n=400)$ were interviewed according to the quota sample. We found out that veterans with a stable military identity mainly had a low level of social adaptability to the civilian life; veterans with a situational form of military identity mostly had a medium level of social adaptability; veterans with an unformed type of military identity were the most adapted to the civilian life.

Keywords: military identity, veterans, social adaptation, stable/unformed/situational forms of military identity.

Батаєва К.В., д-р філос. наук, проф., професор кафедри соиіології та гуманітарних дисииплін Харківського гуманітарного університету “Народна українська академія”, вул. Лермонтовська, 27, Харків, 61000, Україна, email: bataevaekaterina72@yahoo.com, ORCID iD: https://orcid.org/0000-0002-4628-4817, Scopus Author ID: 57204186366,

Артеменко А.Б., канд. сочіол. наук, завідувач кафедри сочіально-реабілітаційних технологій Житомирського економіко-гуманітарного інституту, вул. Вільський Шлях, 18, Житомир, 10020, Україна, email: a.b.renkas@ukr.net, ORCID iD: https://orcid.org/0000-0002-9924-7411

\section{ВПЛИВ МІЛІТАРНОЇ ІДЕНТИЧНОСТІ НА СОЦІАЛЬНУ АДАПТАЦІЮ УКРАЇНСЬКИХ ВЕТЕРАНІВ}

Досліджено вплив різних форм мілітарної ідентичності ветеранів на їх соичільну адаптацію. Мілітарну ідентичність визначено як результат соціальної ідентифікації військовослужбовия

(C) Bataeva E.V., Artemenko A.B., 2021 
з армією через інтерналізацію цінностей і норм, прийнятих у мілітарному полі. Ветеран - ие військовослужбовець, який служив в армії, брав участь у бойових операціях $i$ був демобілізований внаслідок закінчення строку служби або за станом здоров'я, незалежно від роду військ і виду військової служби. Використано соиіологічну методику вимірювання різних форм мілітарної ідентичності ветеранів (стійкої, ситуативної та несформованої) за допомогою таких критеріїв: спрямованість ідентифікащії, біографічна значущість військової служби, сприйняття армії як сім'ї, екзистенційна оцінка військової служби, важливість військових практик після демобілізації, соціальні контакти з колишніми військовослужбовиями, позитивна оцінка військової культури дисциплінованості. Вивчено вплив на формування мілітарної ідентичності ветеранів АТО/ООС таких чинників: термін служби в армії, вік призову, мотивачія до військової служби, сімейний стан і наявність травматичного бойового досвіду. Показано результати дослідження "Мілітарна ідентичність та соціальна адаптація ветеранів АТО/ООС” (2019-2020рр.); за квотною вибіркою опитано 400 ветеранів АТО/ООС $(n=400)$. Виявлено, щуо ветерани зі стійким типом мілітарної ідентичності мають низький рівень соиіальної адаптованості до ичивільного середовища; ветерани зі ситуативним типом мілітарної ідентичності - переважно середній рівень соиіальної адаптованості до иивільного середовища; ветерани з несформованим типом мілітарної ідентичності - переважно високий рівень сочіальної адаптованості до ичивільного середовища.

Ключові слова: мілітарна ідентичність, ветерани, сочіальна адаптація, стійка/несформована/ситуативна форми мілітарної ідентичності.

The study of the phenomenon of veterans' military identity is an essential task in all countries facing the problem of social adaptation of service(wo)men who participated in the international or local armed conflicts. This problem has become especially important in Ukrainian society due to combat operations in the Donbas in the east of the country. According to official statistics, in 2019, 358,576 combatants faced the need to adapt to the civilian environment after returning from the Ukrainian army ${ }^{1}$.

Most studies conducted within a few recent years deal with the identification of psychological parameters of military identity (MI) and study of problems associated with (dis)adaptation of former service(wo)men. At the same time, the literature on this topic lacks sociological research on MI of veterans. Thus, there is a need to develop a sociological methodology for studying the influence of MI on the social adaptation of veterans after their return to civilian life. We define "military identity" because of the social identity of a service(wo)man with the military due to the internalization of values and norms adopted in the military sphere ${ }^{2}$. "A veteran" is a service(wo)man who served in the army, participated in combat operations, and was demobilized in connection with the end of the term of service or for health reasons, regardless of the type of military forces and military service.

\footnotetext{
${ }^{1}$ Information on granting the status of a participant in hostilities (2019, January). Ministry for Veterans Affairs of Ukraine. URL: https://mva.gov.ua/ua/news/informaciya-shchodo-nadannya-statusu-uchasnikabojovih-dij [in Ukrainian]

${ }^{2}$ In our definition, we used the main features of the concept of military identity, proposed by R. Johansen, M. Martinussen, N. Kvilvang: "Military identity is closely tied to the Armed forces' prevailing goals, values, and tasks, representing the degree to which soldiers and officers are motivated and willing to internalize these" [1].
} 
The paper aims to examine the relationship between different forms of MI of veterans and the degree of their social adaptation. To achieve this goal, we will perform the following tasks: present a methodology for measuring the military identity of veterans; identify the factors that influence the formation of different types of MI; reveal the connections between different forms of MI and social adaptability of veterans.

We will distinguish three forms of MI: stable, situational, and unformed. We offer the following definitions of these concepts. A stable form of MI results from social and emotional identification of the service(wo)man with the army that causes the elimination of the previous structure of subjective reality of the individual formed before his/her drafting in the army. A situational ${ }^{3}$ form of MI is characterized by a 'mixed' identification with the army and various civilian social groups; these identifications are likely to vary depending on the context/situation. An unformed type of MI is characterized by a lack of adherence to the military culture or a weak adherence to it and a strong identification of the veteran with various civilian social groups.

Methodology. The theoretical basis of our research is different conceptions and methods for studying MI of service(wo)men/veterans ${ }^{4}$ [4-13], as well as theories of service(wo)men/veterans' transition from the civilian environment to the military environment, and vice versa [3; 14-21]. The most known methods for measuring MI are the Warrior Identity Scale by S. Lancaster, S. Kinchle, S. Castro [8; 9] and the Military Professional Identity Scale for measuring modifications of MI (idealism, professionalism, warriorism, and individualism) by R. Johansen, D. Laberg, \& M. Martinusen [1; 7]. Since the latter method is more suitable for measuring MI of active service(wo)men rather than veterans, we will refer to the main statements of the Warrior Identity Scale method by S. Lancaster, S. Kinchle, \& S. Castro.

The Warrior, Identity Scale method includes the following dimensions of MI: "identity exploration, identity commitment, public regard for the military, private regard for the military, military centrality, military as family, military connection" [9, p. 39]. Using this method, S. Lancaster, S. Kinchle, \& S. Castro conducted an online survey of 1151 former US service(wo)men in 2016. It was revealed that the importance of all dimensions of identity increased depending on the number of years spent in the military; the perception of the military as a family was positively correlated with difficulties of post-deployment reintegration; public support correlates with better adaptability of veterans [9, p. 39].

Let us present the sociological method for measuring MI of veterans that uses some indicators proposed by S. Lancaster, R. Hart, S. Kinchle, \& S. Castro [8; 9].

To determine the social identity of the veteran, one can use the following question: "Whom do you perceive yourself in the first instance?" with options for answers that provide the possibility of "pure" forms of identity ("I am a service(wo)man" or "I am a civilian") or a "mixed" ("I am a service(wo)man and a civilian at the same time"). The rationale for the need to include this and other questions in the methodology for measuring MI of veterans was proposed for the first time in our article [23].

\footnotetext{
${ }^{3}$ Harraway D. uses the concept of situational identity in the context of considering multiple identities [2].

${ }^{4}$ A more detailed discussion of these concepts is presented in our articles [22].
} 
A strong connection with the army can be manifested in the veteran's desire to establish professional continuity between the army and civilian contexts: "I want to have a job where I could apply my military skills (as a security guard, bodyguard, military commissar, etc.)". The strength of connection with the army can be measured with the help of such statements: "I wish I could go back into the military" and "I am proud of my service in the military" [9] that are measured using a 5-point Likert scale ranging from 'I strongly disagree' to 'I strongly agree" . To measure the strength of rejecting the military past, it is advisable to use the opposite indicator - a feeling of regret over years spent in the military: "I often regret my military service" [9].

To measure the degree of the emotional attachment of the veteran towards the military past, one can use the indicator of the biographical importance of military service: "The best time in my life was when I served in the army". It is also possible to use the opposite statement emphasizing the absence of emotional connection with the army: "I never felt emotionally connected with my military unit" [9, p. 39].

Perception of the army as a family and fellow service(wo)men as real friends correlates with a stable form of MI. In this context, firstly, one can use a modified formulation of the indicator proposed by S. Lancaster, S. Kinchle, \& S. Castro [9, p. 39]: "My fellow service(wo)men are my family"; secondly, the parameter of perception of interaction and mutual assistance in the army as a true friendship that has no analogues in the civilian environment: "I experienced a true friendship in the military"; "I have no true friends outside the military".

According to H. Tajfel, groups with which a person identifies him(her)self are supposed to maintain his/her positive self-concept; otherwise, if the group negatively evaluates an individual's contribution to its development, this can lead to his/her distancing from it or, as a last resort, to rejecting it [24]. Accordingly, if a service(wo)man had a negative experience of serving in the armed forces and (s)he was not appreciated and recognized, then this is likely to become a barrier to the formation of MI and lead to the interruption of the process of his/her identification with the army. As for indicators of the recognition of the individual in the army, one can use "a feeling of his/her importance/usefulness" and "mutual respect between service(wo)men": "In the army, I felt that I was doing important work", "In the army, my colleagues/commanders respected me", "In the army, I respected my colleagues/commanders".

It is supposed that a stable MI is likely to correlate with an existential assessment of army service and with the perception of civil life as meaningless and empty ${ }^{6}$. The indicator of the existential intention of the veteran is his/her belief in a deep meaning of military service: "When I served in the army, I realized a significant importance of army service". The following statement can measure the existential assessment of life after demobilization: "After the army, everyday life appears empty and meaningless".

MI is often studied using the activity approach since it is formed in executing such specific military practices as participation in military operations, daily physical training, and

\footnotetext{
${ }^{5}$ All statements in our methodology are measured using this scale.

${ }^{6}$ Existential concepts were also used by J. Grimell in the study of narrative stories of Sergeant Jonas [25].
} 
Bataeva E.V., Artemenko A.B.

military skills development. Thus, one of the indicators of a stable MI is the importance of military practices after demobilization. To measure adherence to military practices, one can use the following statement: "After my return from the army, I continue to go in for physical training, practising self-defence techniques and shooting". Since military brotherhood is an important element of the military culture [10], the veteran intends to maintain social contacts with former service(wo)men to indicate a commitment to the military culture ${ }^{7}$. The following statements can be used to measure it: "I continue to keep in touch (communicate by phone or via the Internet) with veterans". "I am a member of National/Regional Union of Veterans or online groups of veterans"; "I am not a member of these organizations". "If you are a member of these organizations, how often do you take part in their activities"?

MI is associated with military culture that includes adherence to military norms and values in everyday life. For measuring loyalty to the military culture, one can use the parameter of positive assessment of the military culture of obedience/discipline. This parameter can be expressed with such statements: "I liked that everything is clear in the army and that one just has to follow commanders' orders"; "After the army, I lacked control by commanders". If a veteran positively assesses the military culture of obedience after demobilization, this is likely to indicate a stable form of MI.

Table 1 presents indicators of MI that allow distinguishing between three forms of MI.

Indicators of three forms of MI of veterans

\begin{tabular}{|l|l|}
\hline \multicolumn{1}{|c|}{ MI forms } & \multicolumn{1}{|c|}{ Indicators } \\
\hline Stable MI & Identification with the army ("I am a service(wo)man"). \\
Adherence to military experience (a strong desire to return to the army and \\
continue service). \\
Positive assessment of military service (a sense of pride for military service). \\
No regret about the years spent in the army. \\
Desire to have a job where military skills could be applied. \\
Perception of the army as a family. \\
Recognition of the high value of military friendship that is not observed in \\
civilian life. \\
Strong emotional connection with veterans, who should be consulted before \\
making important decisions. \\
Recognition of the biographical importance of military service. \\
Strong sense of the importance of serving in the military. \\
Recognition of mutual respect of military service(wo)men to each other during \\
their service in the army. \\
Recognition of deep meaning in military service. \\
Perception of life outside the army as a meaningless life. \\
Commitment to military practices after demobilization. \\
Proactive maintenance of contacts with former service(wo)men. \\
Regular participation in activities of National/Regional Unions of Veterans or \\
social groups of veterans on the internet. \\
Positive assessment of the culture of obedience and discipline in the army
\end{tabular}

\footnotetext{
${ }^{7}$ As G. Maringira, D. Gibson, and A. Richters emphasize, the fighting brotherhood is a stable social state
} that retains its power in the postdeployment period [10, p. 37]. 


\begin{tabular}{|c|c|}
\hline MI forms & Indicators \\
\hline Situational MI & $\begin{array}{l}\text { Mixed identification with the army and civilian groups ("I am a service(wo)man } \\
\text { and a civilian"). } \\
\text { Medium level of commitment to military experience (a weak desire to return to } \\
\text { the army). } \\
\text { Rather positive assessment of serving in the army. } \\
\text { Regret of some facts of military service. } \\
\text { Consent to work both in the civilian sphere and the sphere with military } \\
\text { specifics. } \\
\text { Perception of the army as a family. } \\
\text { Recognition of the fact that true friends can be both in the army and civilian } \\
\text { life. } \\
\text { Weak emotional connection with veterans, who can sometimes act as advisors } \\
\text { along with relatives or colleagues. } \\
\text { Recognition of the importance of the biographical fact of military service. } \\
\text { Partial recognition of the importance of working in the army. } \\
\text { Partial recognition of mutual respect between military personnel during their } \\
\text { service in the army. } \\
\text { Partial recognition of a profound meaning of military service. } \\
\text { Agreement with the fact that civilian life can also be meaningful. } \\
\text { Partial adherence to military practices after demobilization. } \\
\text { Periodic maintenance of contacts with former service(wo)men. } \\
\text { Irregular participation in activities of National/Regional Unions of Veterans or } \\
\text { social groups of veterans on the internet. } \\
\text { Medium assessment of the culture of obedience and discipline in the army }\end{array}$ \\
\hline Unformed MI & $\begin{array}{l}\text { Civilian identification ("I am a civilian"). } \\
\text { Minor commitment to military experience (No desire to return to the army). } \\
\text { Negative assessment of army service. } \\
\text { Strong regret about military service. } \\
\text { No desire to have a job with military specifics. } \\
\text { No perception of the army as a family. } \\
\text { Refusal to recognize the fact that a true friendship exists only in the army. } \\
\text { Negligible emotional connection with veterans, who should not be consulted } \\
\text { with before making important decisions. } \\
\text { Refusal to recognize the biographical importance of military service. } \\
\text { Lack of a sense of the importance of working in the army. } \\
\text { Doubts about the existence of mutual respect of military service(wo)men to } \\
\text { each other. } \\
\text { Refusal to recognize a deep meaning of military service. } \\
\text { Agreement with the idea that civilian life is meaningful. } \\
\text { No adherence to military practices after demobilization. } \\
\text { No contacts with former service(wo)men. } \\
\text { No membership in the National/Regional Unions of Veterans or no activities in } \\
\text { social groups of veterans of the internet. } \\
\text { Low assessment of the culture of obedience and discipline in the army }\end{array}$ \\
\hline
\end{tabular}
Source: authors' development, partially used data [9; 10].

The advantage of our sociological methodology for measuring military identity is that it allows identifying different types of MI of veterans based on the following criteria: social 
Bataeva E.V., Artemenko A.B.

identification, the strength of connection with the army, biographical importance of military service, perception of the army as a family, recognition of the individual in the army, existential assessment of military service, the importance of military practices after demobilization, social contacts with former service(wo)men, the positive assessment of the military culture of obedience/discipline. Thus, our methodology is complex, in which we combine communicative, behavioural, emotional, existential, identification, and cultural features. In contrast, R. Johansen, D. Laberg, and M. Martinusen used different parameters to measure each MI modification, which made it difficult to carry out their comparative analysis. In addition, the methodology of R. Johansen, D. Laberg, and M. Martinusen is more applicable to the study of MI of active rather than demobilized service(wo)men.

Four hypotheses were proposed in our study:

H1: Low level of military identity among veterans is associated with the high level of their social adaptation to civilian life.

$\mathrm{H} 2$ : If the actor was called up for military service at the age of 18 to 22 , there is a high probability of his/her deep resocialization and adoption of the military culture that is likely to correlate with a stable form of MI.

H3: If an actor joined the army voluntarily and consciously, and the main motive for choosing military life was the idea of defending his/her country, and it is likely to correlate with a stable form of MI.

H4: The extreme experience of watching the death can affect the formation of a stable MI of the service(wo)man and slow down his/her social adaptation process.

Results. Data Collection and Participants. The relevant data were collected within a period from May 2019 to August 2020. The survey was conducted face-to-face with veterans identified through Ukrainian regional and national organizations of veterans. The time for completing the entire questionnaire was approximately from 15 to 30 minutes.

In our study, the general population was $358,576 \mathrm{ATO} / \mathrm{JFO}^{8}$ veterans (2019, January). The sample was 400 veterans selected according to two criteria: 1) the status of a participant in hostilities in ATO/JFO and 2) the period of civilian life after demobilization from 6 months. Most of the respondents (93\%) returned from the army more than one year ago (34\% of the surveyed veterans returned from the zone of combat operations more than two years ago, 59\% - 1-2 years ago, and 7\% - 6-12 months ago). 31\% (124 persons) were women, $69 \%$ ( 276 persons) were men. Adults between the ages of 20 and 58 are represented in the survey sample (the mean age of respondents is 35,2). All interviewed veterans live in cities and villages of central Ukraine (Vinnytsia, Kyiv, Khmelnytsky, Kirovohrad, Zhytomyr regions).

Data Analysis. The Microsoft Office Excel application was used to analyze all the collected data. Descriptive statistics were used to identify certain trends in the formation of MI of veterans and its impact on their social adaptation. Apart from the descriptive statistics, the Pearson correlation coefficient analysis and Spearman's rank correlation analysis were conducted to identify the relationship between significant variables.

\footnotetext{
${ }^{8}$ In Ukraine, the armed conflict in Donbas has been named the Anti-Terrorist Operation (ATO) or the Joint Forces Operation (JFO).
} 
Various MI indicators were measured using a 5-point Likert scale; three groups of veterans were identified. For each respondent, answer points were averaged. Veterans with a stable MI mainly chose answers with 4 or 5 points; veterans with a situational form selected mostly answers with 3 or 4 points; veterans with an unformed type of MI chose answers with 1 or 2 points. The thresholds for distinguishing these groups by points were as follows: from 1 to 2,6 points - for a group with an unformed type of MI; from 2,6 to 4 points - for a group with a situational form of MI; from 4 to 5 points - for a group with a stable form of MI.

Factors determining different forms of MI. According to the results obtained (see Table 2), 35,3\% of veterans have a stable form of MI, $46,7 \%$ - a situational form, and $18 \%$ - an unformed form.

Table 2

Distribution of respondents by MI forms

\begin{tabular}{|l|c|c|}
\hline \multicolumn{1}{|c|}{ MI forms } & Number of respondents & $\%$ \\
\hline Stable MI & 141 & 35,3 \\
\hline Situational MI & 187 & 46,7 \\
\hline Unformed MI & 72 & 18,0 \\
\hline
\end{tabular}

Source: authors' development.

To understand the factors influencing the formation of MI, several factors were analysed: 1) motivation to join the army; 2) conscription age; 3) duration of staying in the combat zone; 4) traumatic combat experience; 5) marital status.

Motivation to join the army. An important factor of the MI formation is the reason for joining the army. Most veterans with a stable MI enlisted in the army voluntarily (56\%) or were already active service(wo)men at the time of the armed conflict in the Donbas (28\%); only $16 \%$ of such veterans were conscripted during mobilization. Most veterans with a situational MI were conscripted during mobilization (60\%); $24 \%$ joined the army as volunteers, and $16 \%$ were active-duty service(wo)men. Most veterans with an unformed MI were also conscripted during mobilization (64\%), $26 \%$ joined the army as volunteers, and $10 \%$ served in the military.

Among motives to join the army ${ }^{9}$ voluntarily, the reasons for doing so by veterans with a stable MI were selected: $75 \%$ strived to defend the fatherland, $9 \%$ dreamed of serving in the army, $4 \%$ wanted to earn money or get certain benefits, $5 \%$ needed to get a job and $7 \%$ desired to be close to loved ones, who were already in the combat zone (see Table 3). Among veterans with a situational MI, 35\% volunteered to serve in the army to defend the fatherland, $4 \%$ had the desire to be close to loved ones, $28 \%$ wanted to earn money or receive certain benefits, and 33\% looked for a job; none of them chose the statement "I dreamed of serving in the army". As for veterans with an unformed MI, $31 \%$ volunteered to serve in the army to defend their fatherland, $32 \%$ strived to get money or specific benefits, and 37\% intended to get a job; and none of them chose other statements.

\footnotetext{
${ }^{9}$ Respondents were allowed to choose only one of these motives.
} 
Bataeva E.V., Artemenko A.B.

Table 3

Answers of veterans to the question: "If you joined the army voluntarily, state the reason for joining the army", \% to those veterans who went to serve voluntarily

\begin{tabular}{|l|c|c|c|c|c|}
\hline \multicolumn{1}{|c|}{ MI forms } & $\begin{array}{c}\text { 'I strived to defend } \\
\text { the fatherland' }\end{array}$ & $\begin{array}{c}\text { 'I always dreamed } \\
\text { of serving } \\
\text { in the army' }\end{array}$ & $\begin{array}{c}\text { 'I desired to be close } \\
\text { to loved ones, } \\
\text { who were already } \\
\text { in the combat zone' }\end{array}$ & $\begin{array}{c}\text { 'I wanted to earn } \\
\text { money or get } \\
\text { certain benefits' }\end{array}$ & $\begin{array}{c}\text { 'I needed } \\
\text { to get a job' }\end{array}$ \\
\hline Stable MI & 75 & 9 & 7 & 4 & 5 \\
\hline Situational MI & 35 & - & 4 & 28 & 33 \\
\hline Unformed MI & 31 & - & - & 32 & 37 \\
\hline
\end{tabular}

Source: authors' development.

Most of them (91\%) joined the army to defend their fatherland, achieve the dream of serving, or support loved ones already in the combat zone. The other $9 \%$ were pragmatists who wanted to earn money in the army, get certain benefits or find a job. We found a higher pragmatic motivation of veterans with situational and unformed forms of MI (respectively, $61 \%$ and $69 \%$ of them joined the army to earn money, get certain benefits or find a job). Thus, there is a higher idealistic motivation of veterans with a stable MI. Thus, hypothesis $\mathrm{H} 3$ was proved.

Conscription age. The study found some correlation between MI forms and the age at which veterans were drafted. In the group of veterans with a stable MI, most respondents were aged from 18 to 22 years (49\%), and from 25 to 35 years (28\%), veterans aged over 36 years constituted about $23 \%$. In the group of veterans with a situational MI, most respondents were aged from 23 to 35 years (30\%), from 36 to 40 (25\%), and 41 to 45 (19\%); only $16 \%$ of them were aged from 18 to 22 years, and $10 \%$ were at the age of over 46 years. In the group of veterans with an unformed MI, there were $19 \%$ of persons aged from 23 to 35 years, $38 \%$ of those who were aged from 36 to 40 years, and $22 \%$ of veterans aged from 41 to 45 years; and only $8 \%$ were aged from 18 to 22 years, and $13 \%$ were over the age 46 years.

Thus, young age is more associated with the formation of a stable MI. This supports hypothesis $\mathrm{H} 2$ on the likelihood of alternation and deep secondary socialization accompanied by the assimilation of military culture by service(wo)men who were conscripted at a young age (from 18 to 22 years) that is likely because civilian identity is not yet finally formed and is more malleable at this age. On the contrary, if an actor is drafted into the military at the age of social maturity (when he/she is 25 years and older) with the already formed identity, then his/her perception of a military reality is more balanced, and his/her assimilation of military culture is more selective. This is supposed to correlate with a less stable form of MI. Therefore, among veterans aged from 25 to 45, there is a significant percentage of those who have a situational form of MI (74\%) and an unformed form (79\%) of MI.

The Pearson linear correlation analysis and Spearman's rank correlation analysis revealed the positive relationship between MI forms and conscription age, $r=0,334$, $\rho=0,380$.

Duration of staying in the combat zone. The study found a correlation between the time spent by the veteran in the combat zone and MI forms. Most veterans with a stable MI spent 
from one to two years (65\%) and more than two years (28\%) in the combat zone; only $7 \%$ of them spent there from six months to one year. Staying in the combat zone for several days or weeks does not affect the formation of a stable MI. Most veterans with a situational form of MI stayed in the combat zone for a period from six months to one year (43\%) and a period from one to two years (45\%); a small percentage of veterans in this group stayed in the combat zone for more than two years $(9 \%)$ or several days/weeks $(3 \%)$. Most veterans with an unformed MI stayed in the combat zone for a period from six months to one year (82\%); $11 \%$ - for a period from one year to two years, and $7 \%$ stayed in the combat zone a few days/weeks (see Figure 1).

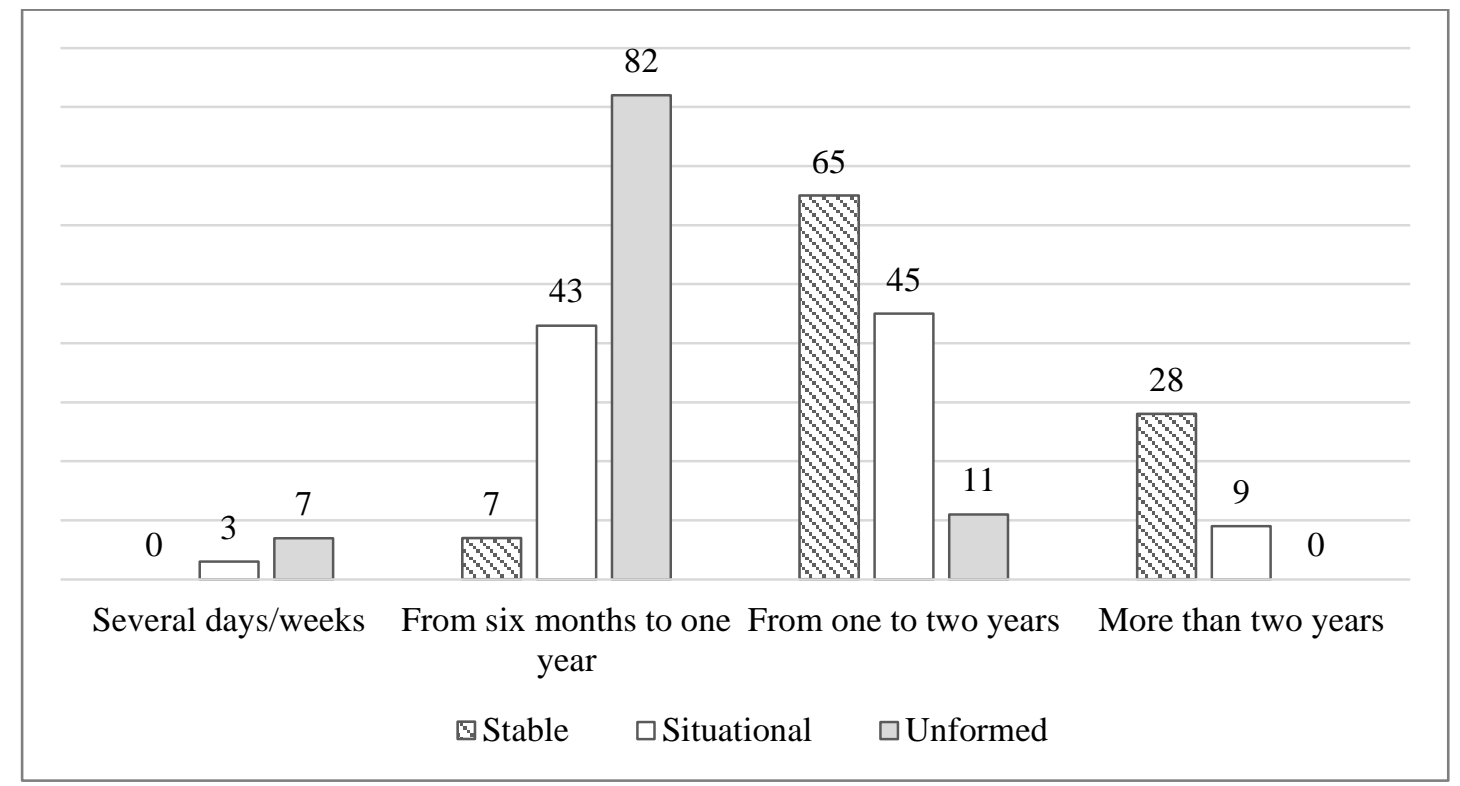

Figure 1. The relationship between the duration of staying in the combat zone and the form of MI, \%

Source: authors' development.

Thus, the duration of staying in the combat zone is correlated with certain forms of MI. Suppose the veteran has spent much time (one or several years) in the combat zone. In that case, this relates to the reproduction of military practices, development of the discipline, establishment of strong, friendly relations with other service(wo)men, emotional commitment to the military that influences the formation of a stable MI. A medium-term staying in the combat zone (from six months to two years) is primarily connected with forming a situational form of MI. As for an unformed MI, it is to a great extent connected with a short-term staying in the combat zone due to which service(wo)men do not have enough time to assimilate values of the military culture. The Pearson linear correlation and Spearman's rank correlation analysis revealed a significant positive relationship between the duration of staying in the combat zone and MI forms: $r=0,498 ; \rho=0,506$. 
Bataeva E.V., Artemenko A.B.

Traumatic combat experience (that includes participation in combat operations, sustained personal injuries/wounds, being in life-threatening situations, the experience of watching the death ${ }^{10}$ (death of comrades, enemies, or civilians)).

Participation in combat operations is an essential factor influencing the formation of a stable MI, as such experience has a significant impact on the service(wo)man's identification with comrades in the extremal situations and the formation of a feeling of belonging to the army. Almost all the veterans with a stable MI (97\%) participated in the combat operations (44\% of them often participated; 53\% did it rarely). On the contrary, a significant percentage of veterans with an unformed MI did not participate in battles (68\%), 28\% did it rarely, and only $4 \%$ often participated in such combat operations. As for veterans with a situational form of MI, 53\% never participated in the military operations, and $47 \%$ participated (35\% - rarely and $12 \%$ - often) (see Figure 2).

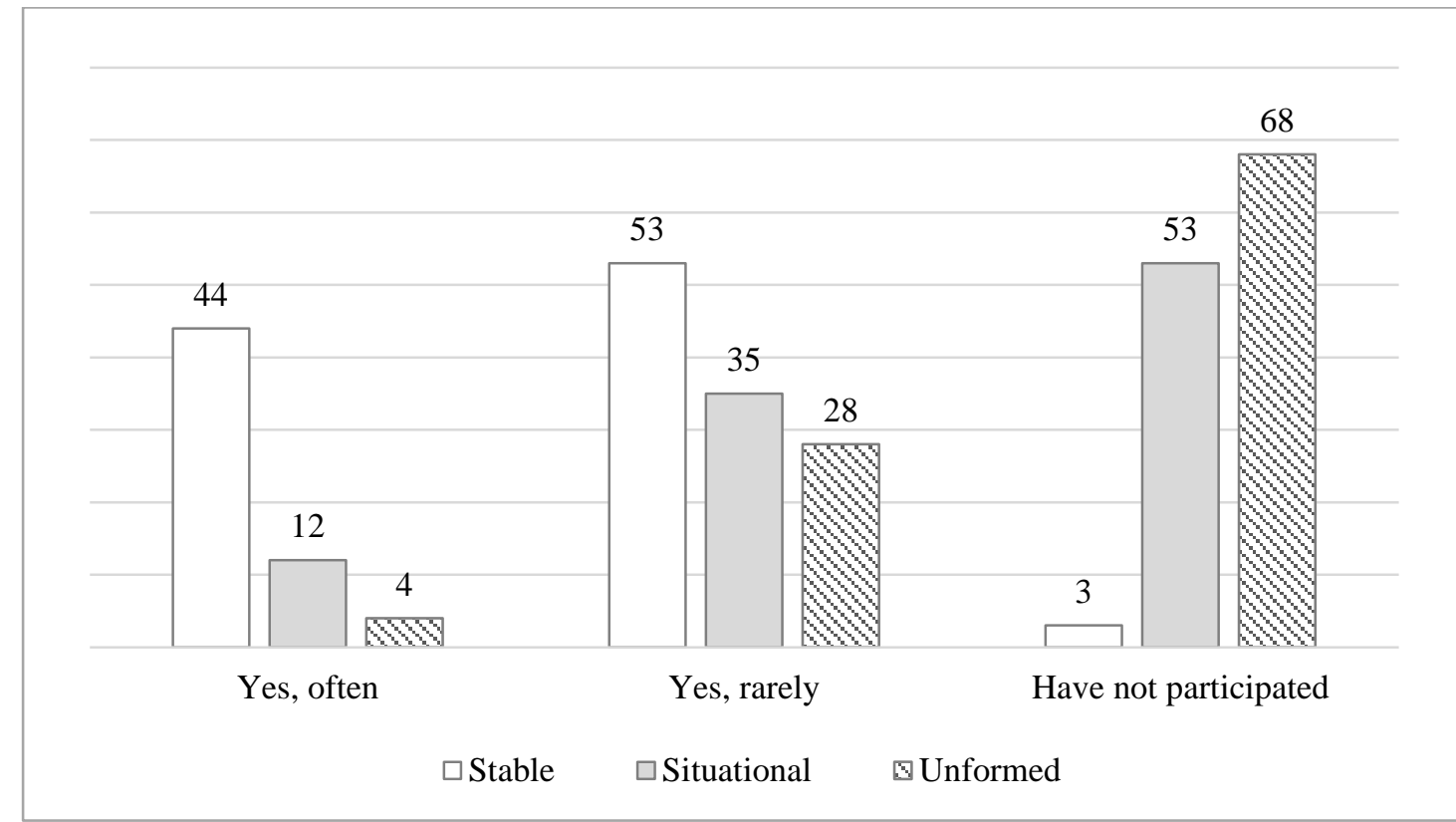

Source: authors' development.

Figure 2. Answers of veterans to the question:

"Have you participated in the military operations", \%

Suffered wounds can also impact the MI formation. It can be assumed that injuries contribute to a deeper awareness of a person's membership in the military. According to our research, $42 \%$ of veterans with a stable MI had injuries (once $-28 \%$; more than once $-14 \%$ ), and 58\% did not have any injuries. Almost all the veterans (96\%) with an unformed type of MI did not have such experience (see Table 4). Most veterans (81\%) with a situational MI had no experience of injuries, $18 \%$ of them were injured once, and $1 \%$ suffered wounds

\footnotetext{
${ }^{10}$ Some authors studied the influence of the meeting with death experience on the formation of MI [26-28].
} 
several times. A significant percentage of veterans with a stable MI had the experience of injuries that are likely to have influenced their worldview and identification with the military. However, for the suffered wounds parameter, the correlation coefficients $r=0,287$, $\rho=0,284$ mean a specific correlation exists, but it is not significant enough. This result is supposed to be obtained due to a low percentage of veterans who had injuries - 98 persons $(25 \%)$.

Table 4

Veterans' answers to the question: "Were you injured?", $\%$ to the number of veterans with a particular type of $M I$

\begin{tabular}{|c|c|c|c|}
\hline MI forms & More than once & Once & I did not have any injuries \\
\hline Stable MI & 14 & 28 & 58 \\
\hline Situational MI & 1 & 18 & 81 \\
\hline Unformed MI & 1 & 3 & 96 \\
\hline
\end{tabular}

Source: authors' development.

The experience of being in life-threatening situations also influences the formation of MI. Most veterans with a stable MI $(89 \%)$ were in such situations $(42 \%$ - often, $47 \%$ - rarely). On the contrary, only $25 \%$ of veterans with an unformed type of MI faced lifethreatening circumstances $(11 \%$ - often, $14 \%$ - rarely), the majority $(75 \%)$ had never faced them. $45 \%$ of veterans with a situational form of MI were in situations when they had thought they would not survive, and 55\% did not survive. Thus, the threat to life and fear of death contribute to identifying service(wo)men with the military that influences the formation of a stable MI.

Most of the veterans with a stable form of MI (84\%) faced the death of their comrades, while $86 \%$ of veterans with an unformed type of MI did not do that (see Figure 3). Among veterans with a situational form of MI, one can see that there is an almost balanced distribution of answers: $48 \%$ witnessed the death of their comrades, and 52\% did not do it. Most veterans with a stable MI saw killed and wounded comrades (63\%) and killed and wounded enemies (85\%). Most veterans with unformed and situational forms of MI did not experience the death or injury of civilians (79\%, in each group). Most veterans with an unformed type of MI (72\%) did not see any killed or wounded enemies (mostly due to their insignificant involvement in military operations), while $56 \%$ of veterans with a situational form of MI witnessed the death of enemies. The experience of watching the death/injury of enemies/civilians is also likely to influence the formation of a stable MI. Hypothesis $\mathrm{H} 4$ was proved, according to which the extreme experience of watching the death influences the formation of a stable MI of the service(wo)man.

We found correlations between forms of MI and certain types of traumatic experiences. For the participation parameter in combat operations, there are correlation coefficients $\mathrm{r}=0,456, \rho=0,494$, which means that there is a significant connection between this parameter and MI. For the experience parameter of watching the comrades' death, there are correlation coefficients $r=0,472, \rho=0,465$, i. e.; there is a significant relationship between the parameter and a stable MI. Conversely, lack of experience of watching the comrades' death correlates with other forms of MI. For the parameter of experience of watching the enemies' death, correlation coefficients $r=0,381, \rho=0,363$ indicate a connection between 
Bataeva E.V., Artemenko A.B.

the parameter and a stable MI is not very strong. For the parameter of experience of watching the civilians' death, correlation coefficients are slightly lower: $r=0,285, \rho=0,328$. For the parameter of being in life-threatening situations, $r=0,385, \rho=0,419$ indicates a correlation between the parameter and a stable MI. Thus, the more intensive the traumatic experience of veterans is, the higher the likelihood of forming a stable MI is, and vice versa.

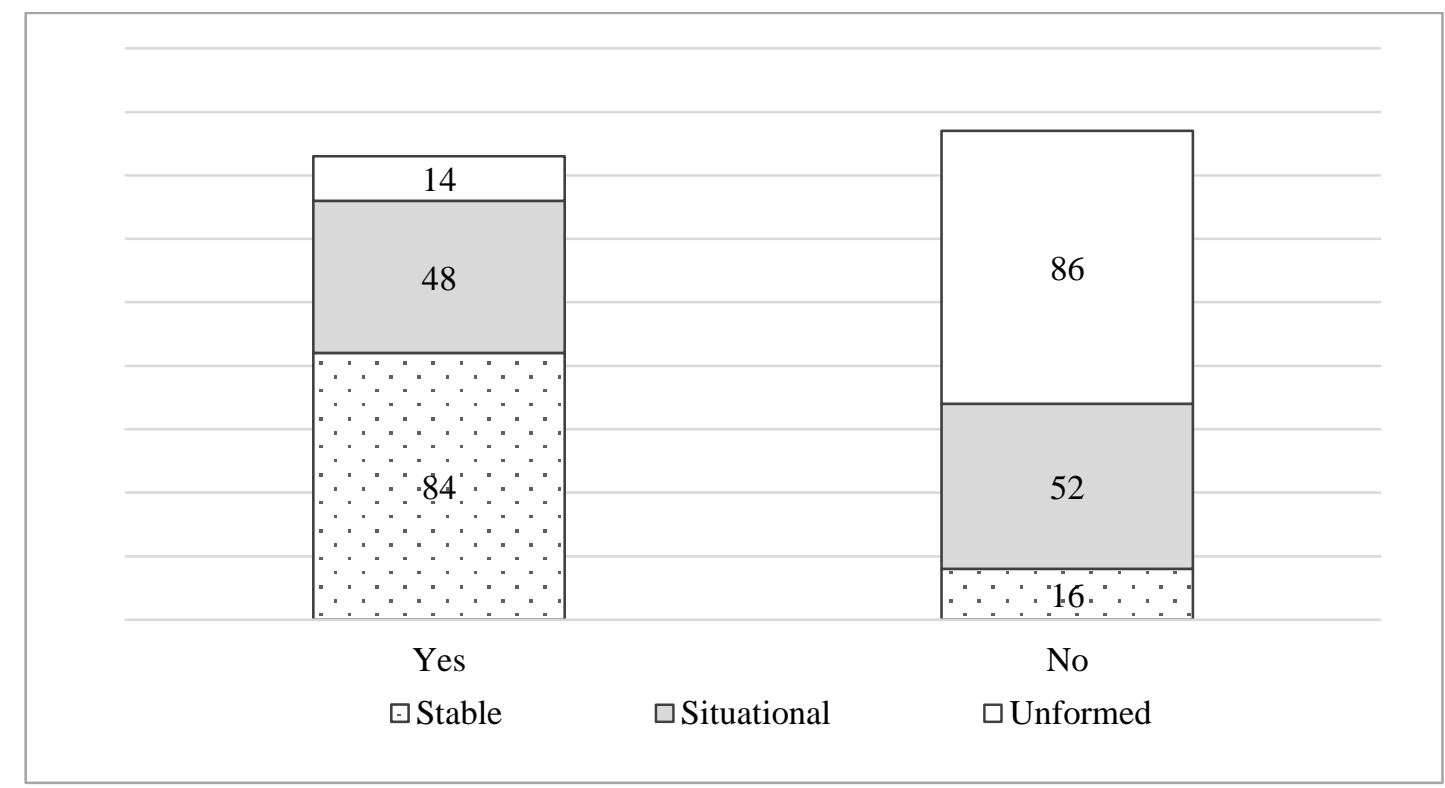

Figure 3. Answers of veterans to the question: "Have you faced the death of your comrades", \% to the number of veterans with a particular type of $M I$ Source: authors' development.

Marital status. The marital status and parental status are likely to correlate with a less stable MI of veterans, as marital status is supposed to "tie" him/her to the civilian sphere and prevent enrolment in the army. According to the study, half of the veterans with a stable MI were never married (50\%); $35 \%$ were married, $14 \%$ were divorced, and $1 \%$ were widows or widowers; most $(71 \%)$ did not have children. On the contrary, most veterans with an unformed MI were married (78\%), 12\% were never married, and $10 \%$ were divorced; $71 \%$ had children. Most veterans with a situational MI were also married (64\%); $21 \%$ were never married, $14 \%$ were divorced, $59 \%$ did not have children.

Coefficients of correlation between the marital status of veterans and MI forms were $r=-0,323, \rho=-0,353$. Since the correlation coefficients are negative, the increase in the level of MI correlates with the non-marital status of veterans and vice versa, but this relationship is not significant enough. It has been found out whether there is a connection between MI of veterans and their parental status. Negative correlation coefficients were found $(\mathrm{r}=-0,281 ; \rho=-0,301)$, which means that the increase in the MI level correlates with non-parental status, and vice versa, but this relationship is also not strong enough. 
Thus, among all the considered factors, the strongest influence on the formation of the types of MI was caused by the following factors: traumatic combat experience $(r=0,609$; $\rho=0,632)$, duration of staying in the combat zone $(r=0,498 ; \rho=0,506)$, conscription age $(\mathrm{r}=0,334 ; \rho=0,380)$, marital status $(\mathrm{r}=-0,323 ; \rho=-0,353)$. Among the various types of traumatic experience, the most significant influence on the formation of types of MI cause the experience of watching the comrades' death $(\mathrm{r}=0,472 ; \rho=0,465)$, participation in combat operations $(r=0,456 ; \rho=0,494)$, being in the life-threatening situations $(r=0,385$; $\rho=0,419)$, the experience of watching the enemies' death $(r=0,381 ; \rho=0,363)$. The lowest correlation was observed for the experience of suffering wounds $(r=0,287 ; \rho=0,284)$, the experience of watching the civilians' death $(\mathrm{r}=0,285 ; \rho=0,328)$.

Military Identity and Social Adaptation of Veterans. Our study aims to identify the relationship between MI forms and the degree of their social adaptation. Social adaptation of veterans means the process and result of the veterans' adaptation to social circumstances after returning from the army to the last place of residence or a new one. To measure the levels of social adaptation of veterans, objective and subjective indicators were used. The objective indicators of the social adaptation include the availability of property for residing and a job, the level of income. Subjective indicators of social adaptation of veterans include satisfaction with the professional activity; satisfaction with living conditions and income; assessment of the life situation; feeling of belonging to the civilian environment; selfassessment of the social adaptation level. We have distinguished the high, medium, and low levels of social adaptation according to these features. A more detailed description of veterans' indicators and levels of social adaptation is presented in our article [29].

Thus, veterans with a stable MI mainly had a low level of social adaptability to civilian life; veterans with a situational MI mostly had a medium level of social adaptability; veterans with an unformed type of MI were the most adapted to civilian life (see Table 5). Significant correlation coefficients were obtained for MI and the social adaptation of veterans $(r=-0,590 ; \rho=-0,617)$. Since the correlation coefficients are negative, the increase in the MI level correlates with a decrease in the level of social adaptation of veterans.

Table 5

Distribution of veterans by a degree of their social adaptation, $\%$

\begin{tabular}{|c|c|c|c|}
\hline \multirow{2}{*}{ MI forms } & \multicolumn{3}{|c|}{ Degree of social adaptation } \\
\cline { 2 - 4 } & High & Medium & 76 \\
\hline Stable MI & 2 & 22 & 11 \\
\hline Situational MI & 30 & 59 & 7 \\
\hline Unformed MI & 72 & 21 & Low \\
\hline
\end{tabular}

Source: authors' development.

Thus, hypothesis H1 has proved: a stable form of MI of veterans is likely to complicate the process of their social adaptation, while situational and unformed types are supposed to correlate with higher efficiency of adaptation to civilian life.

To understand how a particular form of MI influences veterans' level of social adaptation, the indicators of social adaptation are to be considered concerning different forms of MI. 
Bataeva E.V., Artemenko A.B.

Availability of property for residing. Let us use an objective indicator of the availability of property for residing and a subjective indicator of being satisfied with housing conditions. Most veterans with a stable MI did not have their property for residing (resided in rented apartments $(63 \%)$ or lived with relatives (29\%)); only $8 \%$ had their own apartment/house (see Figure 4). Most veterans with a situational MI also rented property for residing (45\%); $32 \%$ lived with relatives, $23 \%$ had their own apartment/house. As for veterans with an unformed MI, $40 \%$ had their own apartment/house; $26 \%$ lived with relatives, 33\% rented property for residing.

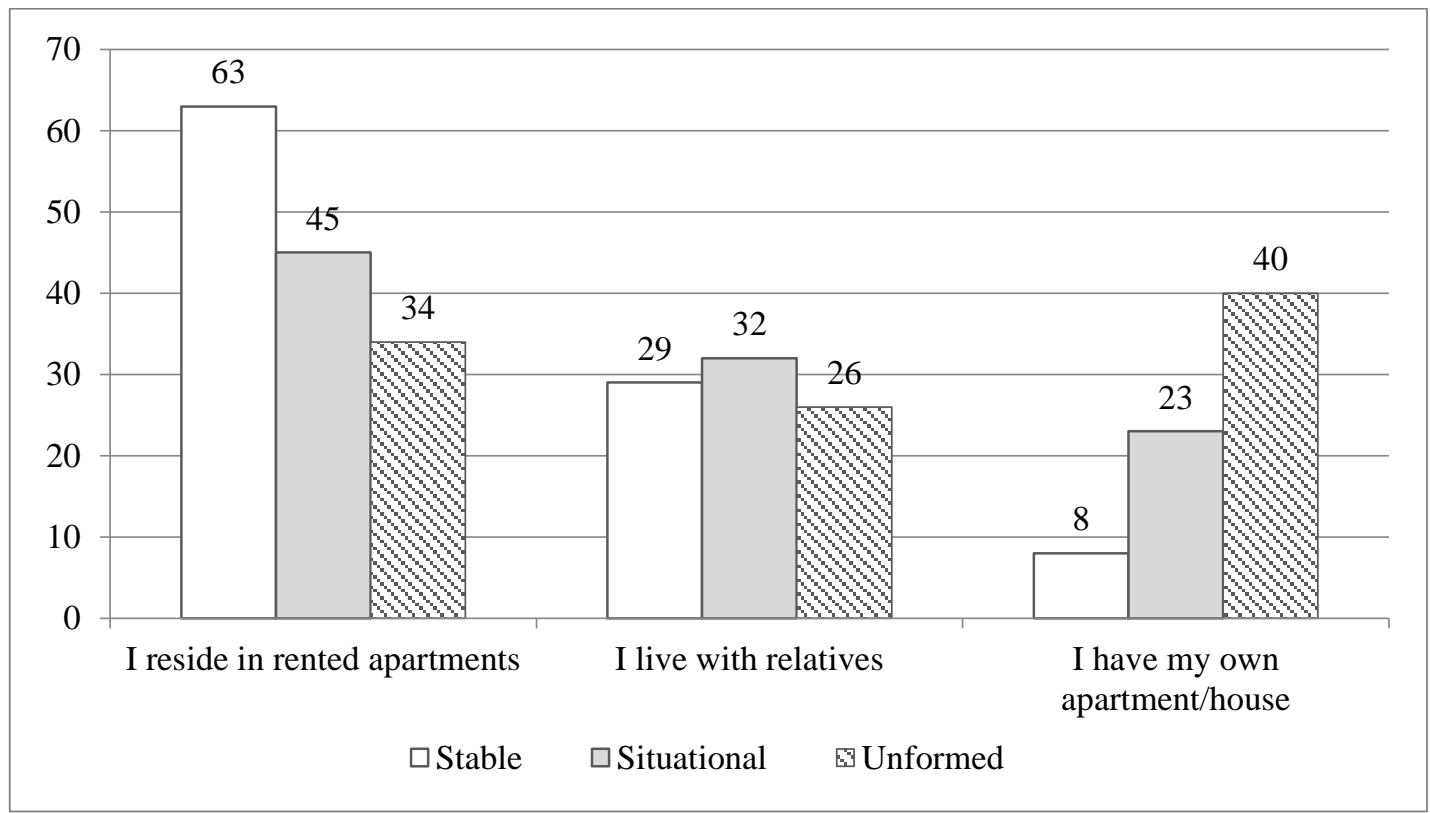

Figure 4. Living conditions of veterans, Source: authors' development.

$\%$ to the number of veterans with a particular type of MI

We considered the indicator of satisfaction with housing conditions in connection with three forms of MI. $69 \%$ of veterans with a stable MI were dissatisfied with their housing conditions; only $7 \%$ were completely or partially satisfied with them, and $24 \%$ of veterans were hesitant about the reply. The highest rate of satisfaction with housing conditions was observed among veterans with an unformed MI - 54\%; only $14 \%$ were dissatisfied; $32 \%$ of veterans failed to provide any clear answer. $60 \%$ of veterans with a situational MI were dissatisfied; $18 \%$ were satisfied; $22 \%$ failed to provide any clear answer. The highest level of satisfaction with housing conditions among veterans with an unformed MI is likely to be explained because this group had the highest percentage of those who had their own apartment/house (40\%).

Employment status. An important role in the social adaptation of veterans is played by their employment status and satisfaction with their jobs; on the contrary, unemployment 
and/or dissatisfaction with professional activities are supposed to result in the formation of a low level of social adaptation.

According to the study findings, $66 \%$ of the veterans with a stable MI were unemployed. This is supposed to indirectly indicate that veterans of this group failed to quickly undergo re-training and find a new job in the civilian environment since they preferred labour of military profile. The highest number of employed persons were observed among veterans with an unformed MI (60\%); $40 \%$ were unemployed. Among veterans with a situational MI, more than half (52\%) were employed. This is likely to indicate that veterans with situational and unformed types of MI can find jobs and adapt to civilian professional activities more easily.

Only those veterans, who were employed, answered the question about satisfaction with their jobs. Most employed veterans with a stable MI were dissatisfied with their work (81\%), of which $71 \%$ were eager to change it, and $10 \%$ did not want to do it. Veterans with a situational form were generally satisfied with their work (85\%), of which $76 \%$ did not plan to look for another job, and $9 \%$ preferred to change it. A high percentage of veterans with an unformed MI were satisfied with their work (84\%), of which $49 \%$ wanted to have a better job, and $35 \%$ did not intend to change it. In terms of the satisfaction with professional activity, veterans with situational and unformed types of MI were better adapted to the civilian professional sphere.

Income level. $86 \%$ of veterans with a stable MI were fixed financially, but they were not able to afford expensive purchases (appliances, furniture) or very expensive purchases (an apartment, car) (60\% and 26\%, respectively); in this group, $14 \%$ of veterans had some financial difficulties (11\% of veterans had problems with buying clothes and medicines; sometimes $3 \%$ of them did not have enough money for food). $78 \%$ of veterans with an unformed MI were fixed financially secured as well, of which $54 \%$ of veterans were not able to afford to buy costly things, and $24 \%$ had no opportunity to buy expensive things; $22 \%$ of veterans with an unformed MI did not have enough money to buy clothes, medicines, and food.

Most veterans with a situational MI (78\%) were fixed financially, but $34 \%$ of veterans were not able to afford to buy costly things, and $44 \%$ were unable to purchase expensive things; $22 \%$ of veterans did not have enough money to buy clothes, medicines, and food (15\% and $7 \%$, respectively).

We have considered the subjective indicators of social adaptation of veterans (assessment of the life situation, feeling of belonging to the civilian environment, selfassessment of the social adaptation level).

Assessment of the life situation. It can be assumed that an optimistic and realistic assessment of one's life indicates a higher social adaptation of a person to life circumstances; a pessimistic assessment is likely to indicate a failure of social adaptation. $44 \%$ of veterans with a stable MI were pessimistic about reality ("everything is bad, I do not hope for the best"), $40 \%$ sounded more realistic ("everything is fine, it could be worse"). Only $16 \%$ of veterans in this group were quite optimistic about life ("everything is OK, it will become even better"). There are almost four times more pessimists in this group than veterans with a situational MI and almost nine times more than in veterans with an unformed MI. 
Bataeva E.V., Artemenko A.B.

The best subjective indicators were observed among veterans with an unformed MI. $24 \%$ of veterans with a situational MI were optimistic about their lives, $66 \%$ were realistic, and only $10 \%$ were pessimistic. In this group, $68 \%$ were optimistic about the circumstances of their lives, $27 \%$ were realistic, and only $5 \%$ were pessimistic.

Feeling of belonging to the civilian environment. A feeling of emotional connection with the place of residence is likely to indicate a person's acceptance of certain social circumstances of his/her existence, loyalty to certain conditions of everyday life that can be considered one of the manifestations of their social adaptability.

Most veterans with a stable MI did not feel any strong emotional connection with the place of residence (64\%), only 3\% confirmed that they had such feeling, and $33 \%$ failed to provide any clear answer (see Table 6). On the contrary, most veterans with an unformed MI (62\%) showed a strong emotional attachment to the place of residence; only $7 \%$ stated that they do not have such feeling; $31 \%$ failed to provide any clear answer. As for veterans with a situational MI, $44 \%$ were emotionally attached to the place of residence, $18 \%$ were not attached to it, and $37 \%$ failed to provide any clear answer. Thus, as far as the subjective criterion of emotional attachment to the place of residence is concerned, veterans with unformed and situational forms of MI were more socially adapted.

Table 6

Veterans' answers to the question:

"Do you feel any strong emotional connection with the place of your residence", $\%$ to the number of veterans with a particular type of MI

\begin{tabular}{|l|c|c|c|}
\hline \multicolumn{1}{|c|}{ MI forms } & Yes & No & Difficult to answer \\
\hline Stable MI & 3 & 64 & 33 \\
\hline Situational MI & 44 & 18 & 37 \\
\hline Unformed MI & 62 & 7 & 31 \\
\hline
\end{tabular}

Source: authors' development.

Self-assessment of the social adaptation level. Based on internal feelings and assessing their public status, persons can somewhat correctly diagnose the degree of their adaptation to a particular social environment. Let us consider veterans' assessment of the degree of their adaptation to the civilian environment after their return from the army.

We have obtained the most detailed and precise results regarding the self-assessment of veterans with a situational MI. $90 \%$ of veterans with a stable MI believed they failed to adapt to the civilian environment; only $3 \%$ believed they managed to do it, and $7 \%$ failed to provide any clear answer. On the contrary, $82 \%$ of veterans with an unformed MI had a high self-assessment of their level of adaptation to the civilian environment; only $8 \%$ had a negative assessment of their adaptation, $10 \%$ failed to provide any clear answer. Most of them $(59 \%)$ hesitated when providing their answers; $29 \%$ identified themselves as those who managed to adapt well, and $12 \%$ declared their failure to adapt. Veterans with an unformed MI believed that their adaptation to the civilian environment was successful, while veterans with a stable MI mainly assessed their transition from military to civilian life as unsuccessful. 
Assessment by veterans of society's attitude to them (at the macro-, meso-, and microlevels). The process of social adaptation of veterans is likely to be facilitated by socio-psychological support provided by family members, surrounding persons, and society in general.

At the micro-level, polar assessments of the attitude of the closest environment depending on the MI form were provided. $28 \%$ of veterans with a stable MI believed that people were generally friendly to them; $57 \%$ said that people were indifferent; $15 \%$ reported an unfriendly attitude (see Table 7). Veterans of the other two groups provided much more positive assessments of attitude to them. $61 \%$ of veterans with a situational MI and $80 \%$ with an unformed MI indicated that surrounding persons were friendly; $23 \%$ of veterans with a situational MI and $14 \%$ with an unformed MI answered that surrounding persons were indifferent to them; $16 \%$ of veterans with a situational MI and 6\% with an unformed MI informed of a hostile attitude to them.

Table 7

Veterans' answers to the question: "How do other people treat veterans?", $\%$ to the number of veterans with a particular type of $M I$

\begin{tabular}{|c|c|c|c|}
\hline \multirow{2}{*}{ Attitude to veterans } & \multicolumn{3}{|c|}{ MI forms } \\
\hline & Stable & Situational & Unformed \\
\hline \multicolumn{4}{|c|}{ In the closest environment } \\
\hline People were generally friendly to veterans & 28 & 61 & 80 \\
\hline People were indifferent to veterans & 57 & 23 & 14 \\
\hline People were generally unfriendly to veterans & 15 & 16 & 6 \\
\hline \multicolumn{4}{|c|}{ In the city/village } \\
\hline People were generally friendly to veterans & 28 & 51 & 81 \\
\hline People were indifferent to veterans & 27 & 29 & 12 \\
\hline People were generally unfriendly to veterans & 45 & 20 & 7 \\
\hline \multicolumn{4}{|c|}{ In Ukraine } \\
\hline People were generally friendly to veterans & 20 & 48 & 21 \\
\hline People were indifferent to veterans & 28 & 38 & 74 \\
\hline People were generally unfriendly to veterans & 52 & 14 & 5 \\
\hline
\end{tabular}

Source: authors' development.

At the meso-level, assessments of veterans with a stable MI were more negative: $28 \%$ believed that people in their settlements were generally friendly to them; $27 \%$ thought that people were indifferent; $45 \%$ believed that they were unfriendly. Assessments of veterans from other two groups practically repeated assessments at the previous level: $51 \%$ of veterans with a situational MI and $81 \%$ with an unformed one had indicated that surrounding persons in their settlements were friendly; $29 \%$ of veterans with a situational MI and $12 \%$ with an unformed MI reported an indifferent attitude of surrounding persons; $20 \%$ of veterans with a situational MI and 7\% with an unformed MI informed of a hostile attitude to them.

At the macro-level, the attitude of Ukrainian society to veterans is of a slightly different character: veterans with a stable MI mentioned a hostile attitude (52\%), an indifferent attitude (28\%), and a friendly attitude (20\%) towards them. $48 \%$ of veterans with a 
Bataeva E.V., Artemenko A.B.

situational MI reported a friendly attitude, 38\% informed of an indifferent attitude, and $14 \%$ made statements about an unfriendly attitude. $74 \%$ of veterans with an unformed MI stated that society was indifferent to their problems; $21 \%$ noted that their attitude was friendly, and $5 \%$ mentioned a hostile attitude.

Thus, most veterans with a stable MI informed them of a generally indifferent or unfriendly attitude at all levels that are likely to hinder their social adaptation. Veterans with other forms of MI were more optimistic in their assessments.

Social support. In the process of social adaptation of veterans, social support provided by family members, surrounding persons, and public authorities plays an important role, so it is necessary to find out what persons/entities in Ukrainian society help veterans the most after their return from the combat zone.

Veterans with all the forms of MI received support mainly at the micro-level - from relatives and friends (see Figure 5). Only $4 \%$ of veterans with an unformed MI, $2 \%$ with a situational MI, and $0 \%$ with a stable MI received support from the state. This explains the negative assessment by most veterans of the Ukrainian society's attitude to them.

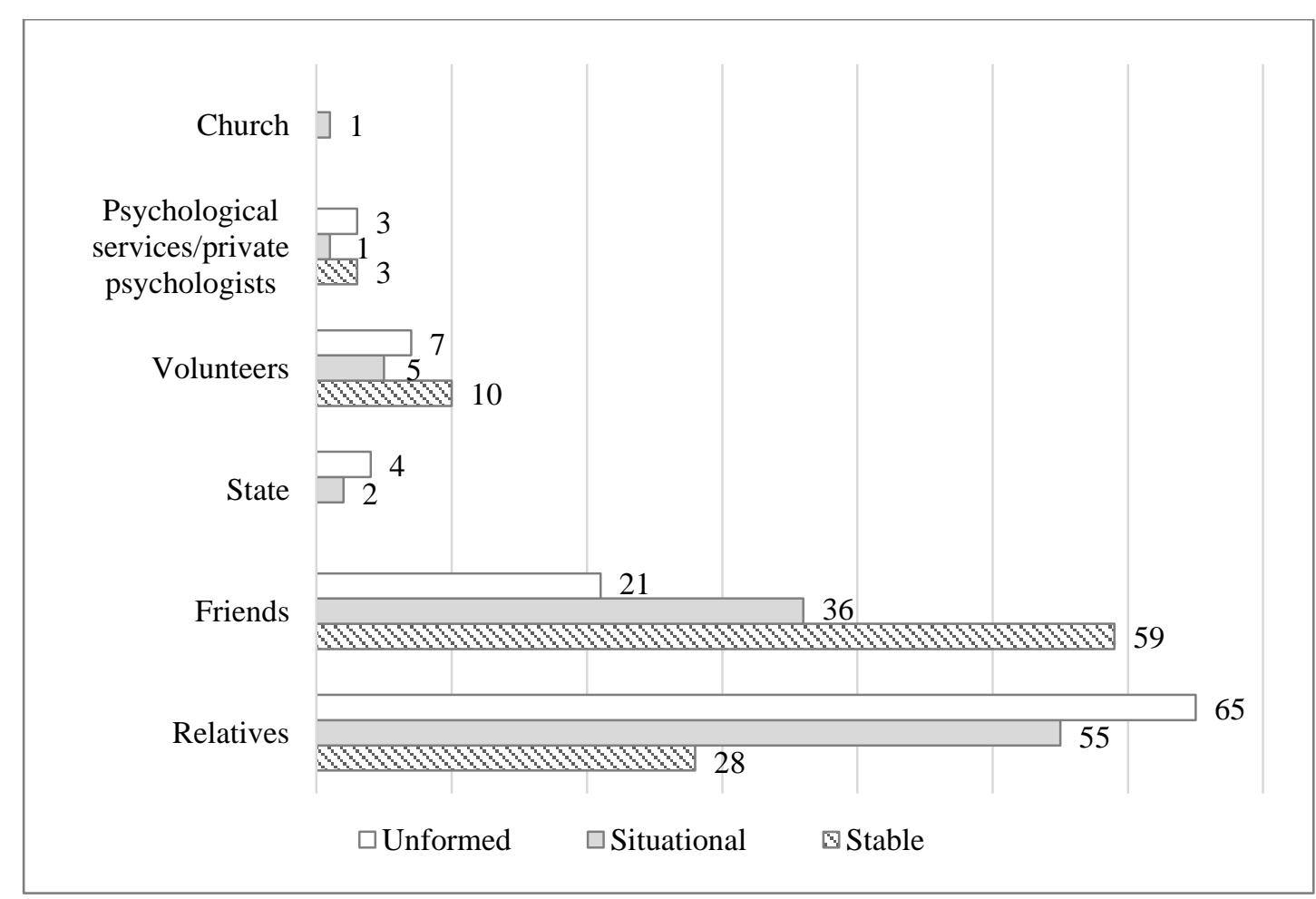

Figure 5. Veterans' answers to the question: "Who helped/helps you to solve various life problems after returning from the combat zone?", $\%$ to the number of veterans with a particular type of $M I$

Source: authors' development. 
A small number of veterans with all the forms of MI received help from psychological services or private psychologists, from church and volunteers. Veterans with unformed and situational forms of MI mainly received such support from relatives $(65 \%$ and $55 \%$, respectively). As for veterans with a stable MI often mentioned support provided by friends (59\%), and only $28 \%$ were informed of assistance rendered by their relatives.

Conclusions. The key findings are as follows:

1) there is a significant correlation between MI of veterans and their social adaptation; veterans with a stable MI mostly had the level of social adaptation to the civilian environment; veterans with a situational form have better social adaptability, and veterans with an unformed MI mostly has a high level of social adaptability;

2) the formation of a stable form of veteran's MI is mainly influenced by an idealistic motivation to join the army voluntarily (to protect the fatherland, be close to the loved ones, achieve the dream of servicing in the army), conscription at a young age (from 18 to 22 years), a long-term duration of staying (for more than a year) in the combat zone, intensive traumatic experience of watching the death and suffered wounds, non-marital status, and non-parental status;

3) the formation of a situational MI of veterans is mainly influenced by a pragmatic motivation to voluntary join the army or join it during mobilization, conscription at the age of social maturity (from 23 to 46 years), a medium-term duration of staying in the combat zone (from six months to one year), the non-intensive experience of watching the death, marital status and parental status;

4) the formation of an unformed MI of veterans is mainly influenced by a pragmatic motivation to join the army, conscription at the age of social maturity (from 23 to 46 years), a short-term staying in the combat zone (up to six months), little experience of watching the death, marital status and parental status;

5) among the types of traumatic experience, the experience of watching the death of comrades/enemies, participation in the combat operations, being in life-threatening situations has the most substantial influence on the formation of various forms of MI; the lowest influence has own experience of suffering wounds and watching the death of civilians.

As a stable type of MI correlates with a low level of social adaptation of a service(wo)man after returning from the army and can complicate the post-army stage in his/her life, as well as having in mind the identified factors influencing the formation of this type of MI, it is necessary to make the following recommendations that should improve the effectiveness of social adaptation of veterans: to increase the age of conscription into the army (starting from 23 years of age, when there is a high probability of the already formed identity); reduce the term of service (from 6 to 10 months with the possibility of returning home for the weekend, as in the Finnish army ${ }^{11}$ ); reduce the time spent in the combat zone (up to 1-2 months); to professionalize military service on a pragmatic motivational basis. Under such conditions, the probability of forming a situational (transitional) type of MI

11 Finland. The alternative service without borders. URL: https://alternativeservice.info/sluzhba-vnegranicz/finlyandiya/ [in Russian] 
Bataeva E.V., Artemenko A.B.

increases, which can be quickly enough transformed into a civilian type of identity after returning from the army.

In the future, it is necessary to conduct a comparative analysis of the process of formation of $\mathrm{MI}$ in male and female veterans and the characteristics of their social adaptation; to find out whether there is a connection between different forms of MI and deviant behaviour of veterans; to investigate what are the core values for veterans with different forms of MI.

\section{References}

1. Johansen, R., Martinussen, M., Kvilvang, N. (2015). The influence of military identity on work engagement and burnout in the Norwegian army rapid reaction force. Journal of Military Studies, 6, 1-11. https://doi.org/10.1515/jms-2016-0196

2. Harraway, D. (1991). Simians, syborgs, and women: the reinvention of nature. New York Routledge.

3. Sokurianska, L., Bataeva, E., Bakirov, V. (2019). Ukrainian veterans in higher education: military identity and educational practices. The Ideology and Politics Journal, 2 (13), 167-184.

4. Cantrell, B.C., Dean, C. (2007). Once a warrior: wired for life. Seattle, WA: WordSmith Books.

5. Eriksson, M. (2004). Idealism or professionalism? Journal of Military Ethics, 7, 75-90.

6. Heinecken, L. (2015). The military, war and society: the need for critical sociological engagement. Scientia Militaria: South African Journal of Military Studies, 43 (1), 1-16. https://doi.org/10.5787/ 43-1-1107

7. Johansen, R.B., Laberg, J.C., Martinussen, M. (2013). Measuring military identity: scale development and psychometric evaluations. Social Behavior and Personality: An International Journal, 41, 861-880. https://doi.org/10.2224/sbp.2013.41.5.861

8. Lancaster, S.L., Hart, R.P. (2015). Military identity and psychological functioning: a pilot study. Military Behavioral Health, 3, 83-87. https://doi.org/10.1080/21635781.2014.995254

9. Lancaster, S., Kintzle S., Castro C. (2018). Validation of the Warrior Identity Scale in the Chicagoland veterans study. Identity: an international journal of theory and research, 18 (1), 34-43. https://doi.org/10.1080/15283488.2017.1410157

10. Maringira, G., Gibson, D., Richters, A. (2015). "It's in my blood": the military habitus of former Zimbabwean soldiers in exile in South Africa. Armed Forces \& Society, 41 (1), 23-42. https://doi.org/10.1177/0095327X14523001

11. Smith, R.T., True, G. (2014). Warring identities: identity conflict and the mental distress of American veterans of the wars in Iraq and Afghanistan. Society and Mental Health, 4, 147-161. https://doi.org/10.1177/2156869313512212

12. Woodruff, T., Kelty, R., Segal, D.R. (2006). Propensity to serve and motivation to enlist among American combat soldiers. Armed Forces \& Society, 32 (3), 353-366. https://doi.org/10.1177/ 0095327 X05283040

13. Woodward, R., Jenkins, K.N. (2011). Military identities in the situated accounts of British military personnel. Sociology, 45, 252-268. https://doi.org/10.1177/0038038510394016

14. Ben-Dor, G., Pedahzur, A., Canetti-Nisim, D., Zaidise, E., Perliger, A., Bermanis, S. (2007). I versus we: collective and individual factors of reserve service motivation during war and peace. Armed Forces \& Society, 34, 565-592. https://doi.org/10.1177/0095327X07303609

15. Blackburn, D. (2016). Transitioning from military to civilian life: examining the final step in a military career. Canadian Military Journal, 16 (4), 53-61.

16. Blackburn, D. (2017). Out of uniform: psychosocial issues experienced and coping mechanisms used by Veterans during the military-civilian transition. Journal of Military, Veteran and Family Health, 3 (1), 62-69. https://doi.org/10.3138/jmvfh.4160 
17. Chicas, J., Maiden, P., Oh, H., Wilcox, S., Young, D. (2012). From war to the workplace: Helping veterans transition to civilian work settings. Center for Innovation and Research (CIR) on Veterans and Military Families. URL: http://cir.usc.edu

18. Cooper, L., Caddick, N., Godier, L., Cooper, A., Fossey, M., Engward, H. (2017). A model of the military to civilian transition: Bourdieu in action. Journal of Military, Veteran and Family Health, 3 (2), 53-60. https://doi.org/10.3138/jmvfh.4301

19. Demers, A.L. (2011). When veterans return: The role of community in reintegration. Journal of Loss and Trauma, 16 (2), 160-179. https://doi.org/10.1080/15325024.2010.519281

20. Higate, P.R. (2001). Theorizing continuity: from military to civilian life. Armed Forces \& Society, 27 (3), 443-460. https://doi:10.1177/0095327X0102700306

21. Robinson, J., Littlefield, P., Schleuning, A. (2017). Transforming veterans' experiences during military-to-civilian transition: gaps and opportunities. Washington, DC: Center for Innovation, U.S. Veterans Administration.

22. Bataeva, E., Artemenko, A. (2018). Concept of Military Identity in Modern Sociology. Visnyk Kharkivskoho natsionalnoho universytetu imeni V.N. Karazina. Seriia "Sotsiolohichni doslidzhennia suchasnoho suspilstva: metodolohiia, teoriia, metody" - Visnyk V.N. Karazin Kharkiv National University. Series "Sociological Studies of Contemporary Society: Methodology, Theory, Methods", 40, 29-35. https://doi.org/10.26565/2227-6521-2018-40-03 [in Russian]

23. Bataeva, E., Artemenko, A. (2018). Methodological aspects of measuring military identity. Ukrainian Sociological Journal, 19 (1-2), 32-42 [In Russian]

24. Tajfel, H. (1982). Social identity and intergroup relations. Annual Reviews Psychology, 33, 1-39.

25. Grimell, J. (2017). Making dialogue with an existential voice in transition from military to civilian life. Theory \& Psychology, 27 (6), 832-850.

26. Castano, E., Yzerbyt, V., Bourguignon, D., Seron, E. (2002). Who may enter? The impact of ingroup identification on ingroup-outgroup categorization. Journal of Experimental Social Psychology, 38, 315-322. https://doi.org/10.1006/jesp.2001.1512

27. Castano, E., Yzerbyt, V., Bourguignon D. (2003). We are one and I like it. The impact of entitativity on social identification. European Journal of Social Psychology, 33, 735-754. https://doi.org/10.1002/ejsp.175

28. Friedman, M.J. (2006). Posttraumatic stress disorder among military returnees from Afghanistan and Iraq. American Journal of Psychiatry, 163 (4), 586-593. https://doi.org/10.1176/appi.ajp.163.4.586

29. Artemenko, A., Bataeva, E. (2020). Methodological aspects of measuring levels of veterans' social adaptation. Technium Social Sciences Journal, 14, 655-660.

Received on 11.05.21 and updated on 11.06.21 